\title{
Minangkabau Proverbs: Values and Functions
}

\author{
Roswita Silalahi \\ English Department \\ University of Sumatera Utara \\ Medan, Indonesia \\ roswita@usu.ac.id
}

\author{
Ely Hayati Nasution \\ English Department \\ University of Sumatera Utara \\ Medan, Indonesia \\ ely@usu.ac.id
}

\begin{abstract}
Pepatah Pepitih' or Minang Kabau (MK) proverb is one of the representations of local wisdoms in supporting nation identity as it contains important values to create better society. This paper aims to analyze character education values proposed by Ministry of Education and Culture of RI (2011) and the functions of MK proverbs by applying descriptive qualitative method focused on content analysis. The text of 249 MK proverbs from the original book, 'Keajaiban Pepatah Minang' written by Saydam (2008) was chosen as the data and 204 of them related to education character was selected as the sample in order to classify Character Education (CE) values in MK proverbs meanwhile Hermeneutics theory was used to analyze the data. Based on the research, it was found that MK Pepatah contains most of education character values; religiosity and democracy are the most dominant values found. In addition, there are also other values found in MK proverbs which can be regarded as local wisdoms; leadership, wisdom, being humble and fair, thriftiness, prudence, and truth. Moreover, MK proverbs has 3 (three) functions; linguistically, educationally, and culturally. Therefore, all values inside surely must be sustained, especially at the education institution as a building block to improve young generations' characters in order to overcome any problems or issues happened in Indonesia.
\end{abstract}

Keywords-character education value; education function; local wisdom

\section{INTRODUCTION}

Indonesia is famous for its culture diversity. It comes in various forms and grows in the society, mixing both indigenous and foreign culture. It also enriches, strengthens, and represents nation identity through its motto 'Unity in Diversity'[2]. One example of Indonesian culture diversities is 'Pepatah pepitih' or Minang Kabau (MK) proverb.

"Pepatah pepitih is a short sentence arrangement with a regular rhythm of sound [4]."

MK proverb has existed and taken important role in MK community. It is used widely and frequently in MK traditional activities, such as birth, marriage, family gathering, death, etc. It is a media for MK community in transferring meaningful messages which certainly reflect the local wisdoms as well as the way of thinking attaching on MK community.

MK proverbs are usually given by the old people during the procession or welcoming speech. They say the proverbs and then explain what it means; the noble values within, such as advice, warning, norm, regulation, etc. The following is one example of MK proverbs for the family member who wants to leave the family for working, studying or travelling.

(1) Aia urang disauak, rantiang urang dipatah, adaik urang dituruik.

(When in Rome, do as the Romans.)

The proverb above means act the way that people around you are acting as people do things differently than you are used to. Based on the example, it can be said that MK proverbs purpose to educate MK people; the philosophy of life or the local wisdoms; how to behave properly and appropriately. It represents that MK proverbs carry the local wisdoms which are required to manage social life.

Ref. [5] defined that the local wisdom is the value of local culture, having been applied to wisely manage the community's social order and social life. It implies that MK proverbs as the representation of local wisdoms play important roles in order to create better society. It is supported by [1] viewing that the society itself consisted of a body of institutions related to the current adaptive needs of a man, it is the study of these institutions (economic and politic systems, education, law, religion, science, family organisation).

Education as a social institution tries to build the character of young generations. It is certainly supported by the government who has committed to improve the character building of young generations through education which is known as 'Character Education (CE)'. According to Charlie (2002) as quoted by [8], 'Character Education is the deliberate effort to help people understand, care about and act upon core ethical values.

It can be stated that $\mathrm{CE}$ orientates on 3 (three) aspects, namely cognitive (thinking), affective (emotion/feeling), and psychomotor (physical/kinesthetic) [3]. Moreover, CE itself contains 18 (eighteen) values proposed by the Ministry of National Education (2011) developed by [7], they are:
1. religiosity
10. patriotism
2. honesty
3. tolerance
11. nationalism
4. discipline
5. hard work
6. creativity
7. independence
8. democracy
9. curiosity
12. highly regard achievement
13. being friendly/communicative
14. being fond of reading
15. peace maker
16. environmental awareness
17. social awareness
18. responsibility

The CE values above are also being universal values declared by Lickona (1997) as quoted by [4] which help to enhance the character building of young generations and 
maintain the local wisdoms. Those values are: honesty, respect, tolerance, prudence, responsibility, discipline, helpfulness, fairness, compassion, cooperation, and courage.

Furthermore, [3] emphasized 7 (seven) elements of culture: language, knowledge system, social organization, living system equipment and technology, livelihood system of life, religion system, and arts. Obviously, it can be said that education is a part of social institution as well as element of culture. Through education, the local wisdoms of a community, especially the proverbs can be sustained since the education itself aims to improve the character building.

In contrast, the development of increasingly globalization has eroded the character values of the youngsters. They tend to less care about the importance of proverbs. They seem to put traditional values as something which is outdated for modern era [6]. Therefore, this research tries to analyze the education values and describe the functions of MK proverbs, especially at education institution.

\section{METHOD}

This research used descriptive qualitative method focused on content analysis. The text of $249 \mathrm{MK}$ proverbs from the original book, 'Keajaiban Pepatah Minang' written by Saydam (2008) was chosen as the data and 204 of them related to education character was selected as the sample in order to classify Character Education values proposed by the Ministry of National Education (2011) meanwhile Hermeneutics theory was used to analyze the data.

\section{FINDINGS AND DISCUSSIONS}

Based on the study done, it is found that MK proverbs teach all education character values, as shown in the following table.

TABLE. 1.

EDUCATION CHARACTER VALUES IN MINANGKABAU PROVERBS

\begin{tabular}{|c|l|c|c|}
\hline No. & \multicolumn{1}{|c|}{ Character Education Values } & Total & $\begin{array}{c}\text { Percentage } \\
(\boldsymbol{\%})\end{array}$ \\
\hline 1. & Religiosity & 30 & 12.05 \\
\hline 2. & Honesty & 2 & 0.80 \\
\hline 3. & Tolerance & 5 & 2.01 \\
\hline 4. & Discipline & 5 & 2.01 \\
\hline 5. & Hard work & 9 & 3.61 \\
\hline 6. & Creativity & 10 & 4.02 \\
\hline 7. & Independence & 4 & 1.61 \\
\hline 8. & Democracy & 52 & 20.88 \\
\hline 9. & Curiosity & 11 & 4.42 \\
\hline 10. & Patriotism & 6 & 2.41 \\
\hline 11. & Nationalism & 4 & 1.61 \\
\hline 12. & Highly regard achievement & 3 & 1.20 \\
\hline 13. & Being friendly/communicative & 6 & 2.41 \\
\hline 14. & Being fond of reading & 8 & 2.81 \\
\hline 15. & Peace maker & 4 & 3.21 \\
\hline 16. & Environmental awareness & 10 & 4.61 \\
\hline 17. & Social awareness & 5 & 2.01 \\
\hline 18. & Responsibility & 68 & 27.30 \\
\hline 19. & Others & 249 & 100 \\
\hline & Total & & \\
\hline & & 7 & \\
\hline
\end{tabular}

Religiosity and democracy have the highest percentage of all. It means that MK community honor highly on religiosity and democracy in their life, as described in the following proverbs:

(2) Kepalang alim, rusak agama

(When mufti is less knowledgeable, then religion will be disable)

(3) Elok diambiak jo etongan, buruak dibuang jo mupakaik.

(Making decision through voting is good; the better is agreement)

The first proverb talks about religiosity which emphasizes on the key role of a mufti; as a leader as well as an expert. Once the mufti cannot apply the lessons related to the religion well and wisely, then many problems will follow, meanwhile the second proverbs talks about agreement. For MK community, discussion for agreement is better than voting for it can avoid any conflicts or differences occur.

The descriptions of meaning of both proverbs denote that the value of religiosity and democracy are significantly required not only by $\mathrm{MK}$ community but also by all communities in Indonesia as a multicultural country in order to overcome any problems exist, particularly those related to the character building and culture recently.

It obviously points that MK proverbs can be alternative or function in education institution in order to empower the education character values, as illustrated in the following illustration.

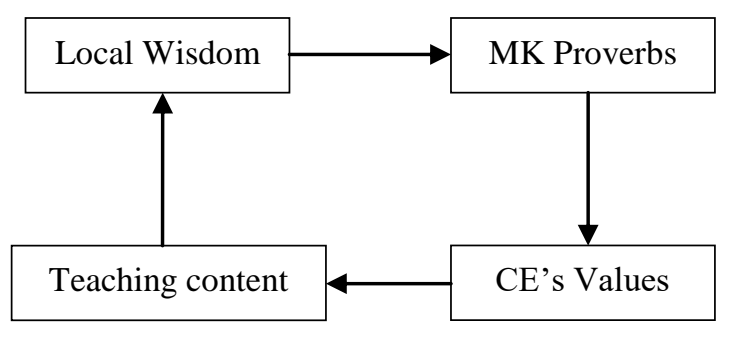

Illustration 1. Educational Function of Minangkabau Proverbs

MK proverbs as the representation of local wisdoms teach valuable values which also embrace the character education values. Thus, it is really important to arouse the use and the function of MK proverbs, for instance as a teaching content in educational institution. For some lessons in the high school, such as English, Bahasa, Social Science, etc., the content of proverbs are very limited. For example in learning English. Most textbooks are only focused on English proverbs without trying to link it with Indonesian proverbs. The explanation of the meaning inside is also often regardless. Therefore, it can be an alternative to popularize MK proverbs so many people will know more about them, not only the content but also the meaning as the proverbs indirectly carries 3 (three) main functions; linguistically (Minangkabau language), educationally (character education values), and culturally (understanding more about MK customs )

Moreover, there are also other values found in $\mathrm{MK}$ proverbs which can be regarded as local wisdoms; leadership, wisdom, being humble and fair, thriftiness, prudence, and truth, as seen in the following. 
(4) Alang tukangbinaso kayu, alang cadiak binaso adaik, alang arih binaso badan

(An unskillful carpenter will break the wood, unintelligent leader will destroy the custom, and unwise person will defeat himself.

That proverb points out three (3) important values of local wisdoms; they are intelligence, leadership, and wisdom. Despite the proverbs were created long time ago, but the values within are extant until now and are really appropriate as a solution to resolve the existing issue.

\section{CONCLUSION}

MK proverbs as the representation of local wisdoms contain all character education values within; religiosity and democracy are the most dominant values found which infer that MK community is identic with those values or characters. Moreover, MK proverbs has 3 (three) functions; linguistically, educationally, and culturally. Therefore, all values inside surely must be sustained, especially at the education institution as a building block to improve young generations' characters in order to overcome any problems or issues happened in Indonesia.

\section{REFERENCES}

[1] "Bronislaw Malinowski and (individual) functionalism in IBCSA", Available:https://ibsca.wikispaces.com/file/view/Malinowski+and+Functi onalism.pdf

[2] E.H. Nasution and R. Lubis, "Character education and universal values in Toba Batak's Umpama”, in Proc. ICCLW, 2016, p. 265.

[3] Koentjaraningrat. "Pengantar ilmu antropologi", Jakarta: PT. Rineka Cipta, 1990.

[4] G. Saydam, "Keajaiban pepatah Minang”, 1st ed., Bandung: CV. Pustaka Setia, 2010.

[5] R. Sibarani, "Kearifan lokal: hakikat, peran, dan metode tradisi lisan", Jakarta: ATL, 2012.

[6] R. Silalahi, "Life philosophies of Toba Batak community in the movie with Indonesian subtitle, in Proc. Educational Creativity and Innovation in Perspectives of The Asean - China Relations, 2015.

[7] Suyadi, "Strategi Pembelajaran Pendidikan Karakter", Bandung: Remaja Rosdakarya, 2013.

[8] U. Qoyyimah, "Theories of moral education and implementation in Indonesia: Re-energizing cultural identity and addressing future challenges", in Proc. The international conference on education research and development: Trend and challenges toward Asian economic community, p.1. 2015. 